\title{
The R3-N3 and R5-N5 Palaeomagnetic Transition Zones in SW-Iceland Revisited
}

\author{
Leo KRISTJANSSON and Magnus SigURGEIRSSON \\ Science Institute, University of Iceland, Dunhaga 3, 107 Reykjavik, Iceland \\ (Received October 16, 1991; Accepted May 20, 1992)
}

\begin{abstract}
We present the results of geological and palaeomagnetic mapping of several lava profiles in Southwestern Iceland, covering a transition from reverse to normal polarity about 2 M.y. ago. The transition was first described by SIGURGEIRSSON (1957). We confirm that the virtual-pole path of this transition is not confined in longitude. We also present and discuss instances of complex pole paths in older strata in Iceland, and we provide new evidence for the general reliability of palaeomagnetic directions from lava flows.
\end{abstract}

\section{Introduction}

Thorbjörn Sigurgeirsson's pioneering work in palaeomagnetism in the mid-1950's was a remarkable achievement in view of the limited research facilities available to him at that time. His mapping, with Trausti Einarsson, of the palaeomagnetic polarity groups in the lava pile of Iceland had a profound effect on the general understanding of this subject. Their papers at the Nov. 1956 Rock Magnetism conference in London (EINARSSON, 1957; SIGURGEIRSSON, 1957) also provided the first convincing demonstration of intermediate virtual-pole positions, thus contributing to the acceptance of frequent "field reversals" of a weakened geomagnetic dipole rather than "self-reversals" in minerals.

The most complete pole path described by SIGURGEIRSSON (1957) occurred at the boundary between the magnetic polarity zones named R 3 and N 3 in south-west Iceland, R3 being the lower, reverse zone and N3 the upper, normal zone. In spite of considerable sampling effort in many regions of the country since then, few if any more continuous geomagnetic pole paths have yet been found in the lava pile.

In view of the historical importance of Sigurgeirsson's work and the general level of earth science research activity in Iceland, one might expect the SW-Iceland area to have been thoroughly mapped by now, with detailed palaeomagnetic and age-dating studies being included. Unfortunately, this is not so. Efforts at mapping several isolated parts have indeed been made, but most are only described in unpublished undergraduate theses. Much of the subsequent palaeomagnetic research in the area has also been incompletely reported. Due to alteration problems, only a single K-Ar dating has been made in the vicinity of the R3-N3 transition (KRISTJANSSON et al., 1980), and correlation of the short N3 zone to international polarity time scales (which may themselves be erroneous) cannot be made unambiguously. $\mathrm{N} 3$ or the transition has not been positively identified elsewhere in Iceland.

The present authors initiated in 1989 a new mapping effort of the R3-N3 boundary, using standard geological and palaeomagnetic techniques. One of the aims of this mapping has been to locate lava material of promising quality for palaeointensity measurements. In this preliminary study, we have been guided by T. Sigurgeirsson's field and laboratory notebooks. Below, we report the results from our work, reviewing previous published and unpublished research as we go along.

\section{Previous Work on the R3-N3 Transition}

Using a field compass, Sigurgeirsson and Einarsson mapped a series of 15 polarity zones in WIceland in 1953-56. These were numbered consecutively backwards in time, beginning with the present 
(Brunhes chron) as N1. The thickness of the zones was variable, both laterally (in part due to stratigraphic complexities caused by glaciations during the building up of the lava pile) and from one zone to another. A generalized polarity column for the area around the fjord Hvalfjördur, based on EINARSSON (1957), is shown in Fig. 1.

At some polarity boundaries, Sigurgeirsson and Einarsson noted the presence of lavas having intermediate directions of magnetization. At these locations, Sigurgeirsson collected hand samples weighing 1-2 kg, generally one from each lava. They were all oriented with reference to the Sun or geographic bearings: a horizontal glass slide was attached to each sample by plaster of Paris, and the azimuth of a scratch line on the slide was found by means of a prism and a sighting compass. The remanence of the hand samples was measured with a spinner-type magnetometer. Alternating field (AF) demagnetization was made at $11 \mathrm{mT}(110 \mathrm{Oe})$ peak field. Detailed direction results for one of Sigurgeirsson's profiles (without tilt correction) were published by BRYNJOLFSSON (1956).

Other data from Sigurgeirsson's transition work has only been published in the form of small-scale maps of virtual geomagnetic pole (VGP) positions after correction for tectonic tilt, assumed to be $4^{\circ}$ in a direction $120^{\circ}$ east of north. Figure 1 of SIGURGEIRSSON (1957) includes high-latitude palaeomagnetic poles from 59 units in polarity groups N1 through R3. Figure 3 of his paper also reports poles from 26 transitional units in seven short profiles numbered A to G across the R3-N3 boundary (our Fig. 2), and 19 units at three other polarity boundaries. Geological information on the R3-N3 sampling sites was not reported in Einarsson's or Sigurgeirsson's publications.

WILSON et al. (1972) resampled and extended Sigurgeirsson's profile C in 1964. Hand samples were collected in this profile. The only palaeomagnetic details from Wilson et al.'s collection in SW-Iceland which have been published are polarity columns and pole-position maps in their 1972 paper. SHAW (1975)

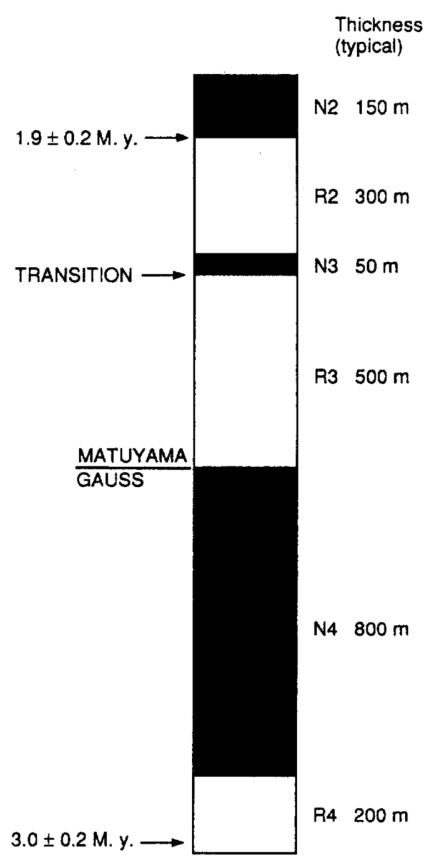

Part of SW-Iceland lava pile (after Tr. Einarsson)

Fig. 1. Generalized polarity column for the lava pile around Hvalfjördur fjord. Ages on the left hand side are those quoted by KRISTJANSSON et al. (1980, with new decay constants) and GEIRSDOTTIR (1991, average of two K-Ar dates). 


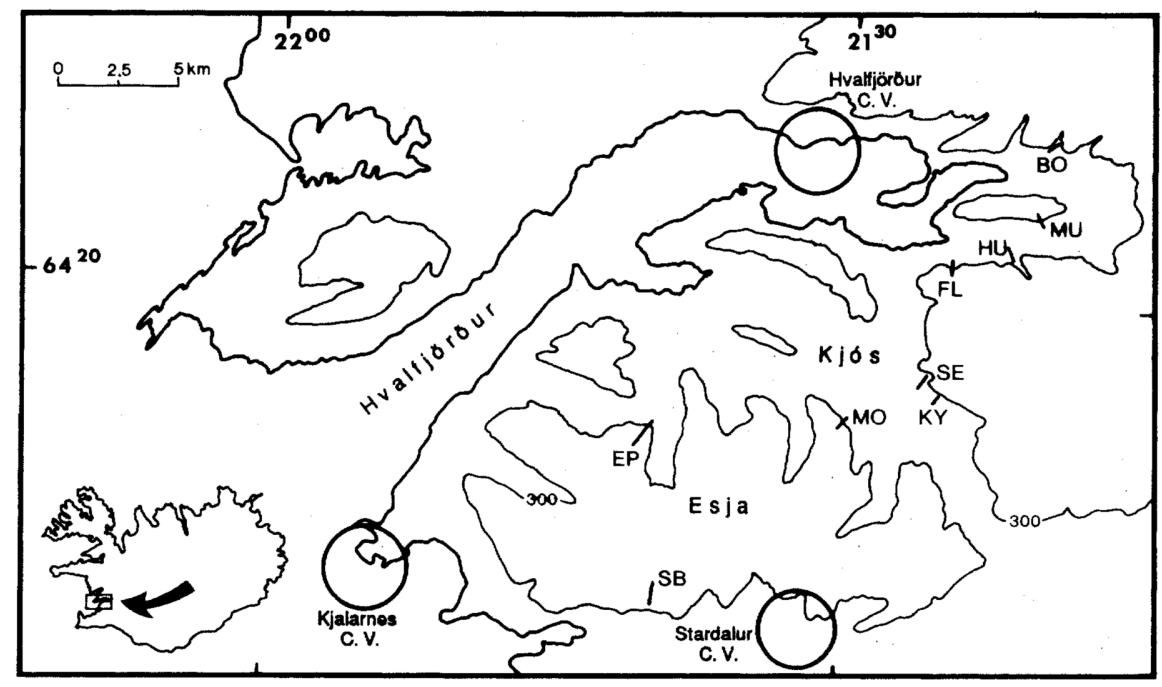

Fig. 2. Location of palaeomagnetic sampling profiles across the R3-N3 boundary south of Hvalfjördur. See Fig. 2 of SIGURGEIRSSON (1957) for comparison.

sampled in several of the R3-N3 profiles for palaeointensity measurements; however, his paper only presents pole positions and no detailed information on locations or stratigraphy. Profiles $F$ and $G$ of Sigurgeirsson's were resampled by KRISTJANSSON et al. (1980), who used portable drills for collecting. The assumed tectonic tilt for the lavas included in their Table 1 was $5^{\circ}$ in a direction of $135^{\circ} \mathrm{E}$.

\section{Geological Setting}

The area of investigation (Fig. 2) is located at around latitude $64^{\circ} 20^{\prime} \mathrm{N}$, longitude $21^{\circ} 30^{\prime} \mathrm{W}, 10-30$ $\mathrm{km}$ west of the currently active Reykjanes-Langjökull volcanic zone. Tectonic tilts are generally $5-7^{\circ}$ to the SE or ESE, towards the active zone. The Esja area has been geologically mapped in detail by FRIDLEIFSSON (1973), and east of Esja mapping was carried out in the nineteen-seventies by University of Iceland undergraduate students supervised by Kristjan Saemundsson.

Three central volcanoes were active in during the time when this part of the basalt lava pile was being emplaced, in time order the Hvalfjördur, Kjalarnes and Stardalur centers. The first one of these centers was active during the Gauss geomagnetic chron, thus producing lavas of normal polarity. The oldest lava flows from the Kjalarnes center are also normally magnetized and of Gauss age, but the main body of lavas from this volcano is produced during the Matuyama and is hence of reverse magnetization. As the Kjalarnes volcano became extinct, the activity moved east with the commencement of volcanism at the Stardalur center. It is believed (FRIDLEIFSSON, 1973, 1985) that there was no break in lava production at this time, and that the two centers cover the time interval 2.8-1.8 M.y. ago, i.e. to the middle Matuyama. The lava sequences belonging to the Stardalur volcano include two normally magnetized subchrons, N3 which is discussed in the present paper, and the younger N2.

The upper parts of the mountains east of Hvalfjördur and north of Esja are in the chabazite-thomsonite regional zeolite zone as defined by WALKER (1960), indicating that $500 \mathrm{~m}$ of erosion has taken place, down to the present mountain-top level (FRIDLEIFSSON, 1973; KJARTANSDOTTIR, 1976).

The formations in the research area are emplaced after the onset of cold climates in Iceland, which has had a profound effect. The oldest cold-climate deposits in Western Iceland are dated at about 3 M.y. (MCDOUGALl et al., 1977; GEIRSDOTTIR, 1991). The main evidence for cold or glacial conditions is the presence of tillites and localized hyaloclastite units which may have been produced in subglacial 


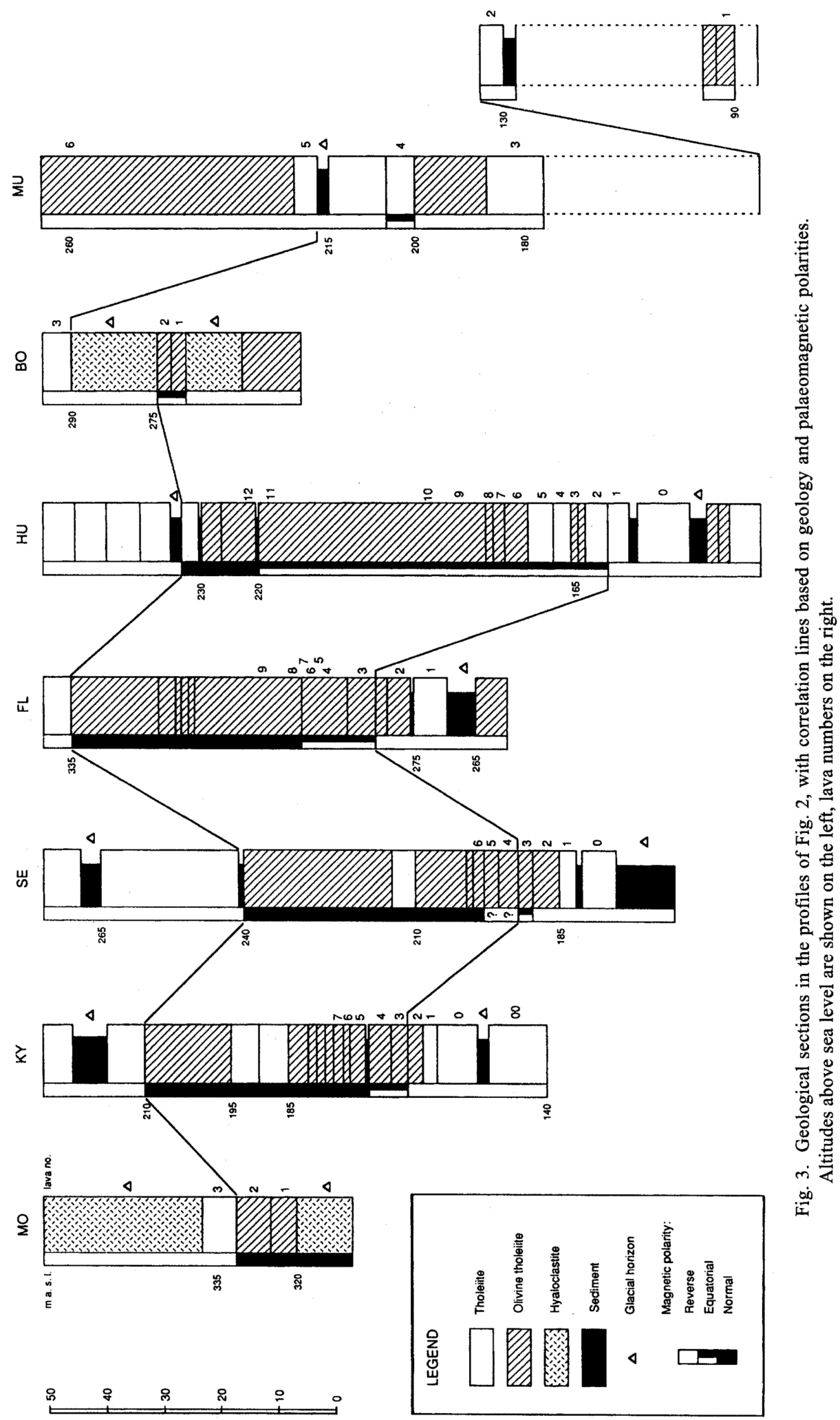


eruptions. In the Esja area, the occurrence of at least 10 glacial episodes is indicated in the profiles sampled by KRISTJANSSON et al. (1980). Two such cold-climate periods can be seen in the present study, cf. profiles $\mathrm{SE}$ and KY in Fig. 3. In interglacial times lavas have flowed across the eroded remnants of the clastic formations and gradually covered them. Due to these circumstances, the contemporaneous sequences of Fig. 3 may look quite different from profile to profile. However, the formations are broadly similar to those decribed in mt. Esja by KRISTJANSSON et al. (1980) and can be correlated with their profiles EP and SB.

The main part of the research area is outside any direct influence of the volcanic centers, as is seen from the general scarcity of differentiated rocks and intrusions. Closeness to a volcanic center is most evident in the ridge Mödruvallahals (profile MO) where dikes originating from the Stardalur volcano can be seen (cf. FRIDLEIFSSON, 1985). In this section only the bottom part of N3 is preserved.

In the gullies Kyrgil and Selgil (profiles KY, SE) as well as in Thrandarstadafjall mountain (FL, HU) the eruption of lavas has proceeded quite regularly: characteristic thick tholeiite lavas and olivine tholeiite basalt units (compound flows) can be traced for long distances. It is likely that these lavas were emplaced in a similar way as lavas are being erupted in postglacial times on the Reykjanes peninsula, the westernmost exposed part of the SW-Iceland volcanic zone. Here, tholeiite lavas are produced by fissure eruptions and olivine tholeiites by shield volcanoes at the margin of the active zone. There are usually no clastic interbeds between the latter type of lavas, which indicates that they were erupted in short intervals compared to tholeiites where interbeds are common. In the above four profiles, the R3-N3 transition occurs near the base of a thick olivine-tholeiite compound flow.

In our profile BO in Botnsdalur valley, only two transitional flows occur between thick hyaloclastites, but T. Sigurgeirsson (unpublished) located one normally magnetized flow nearby. Likewise, one transitional but no normally magnetized lavas were seen in our profile MU: here, the thin N3 zone may be hidden by scree.

\section{Palaeomagnetic Methods and Results on the R3-N3 Transition}

Following detailed geological and palaeomagnetic polarity mapping, the transition profiles were sampled with portable drills. Four oriented cores were generally taken from each of the numbered units of Fig. 3. Remanence measurements utilized an Institut Dr. Förster four-probe static fluxgate magnetometer. AF demagnetization was carried out at 10,15 and $20 \mathrm{mT}$ (occasionally $25 \mathrm{mT}$ ) peak field, using a Molspin tumbling demagnetizer. Each palaeomagnetic direction in Table 1 is the mean giving highest precision (for all samples demagnetized at the same field). A few unstable or discordant samples were rejected. A single tilt correction value of $5.5^{\circ}$ to the southeast was used for the data of Table 1. In Fig. 3, lavas having low-latitude virtual poles appear to form a stratigraphic horizon which is consistent with other means of

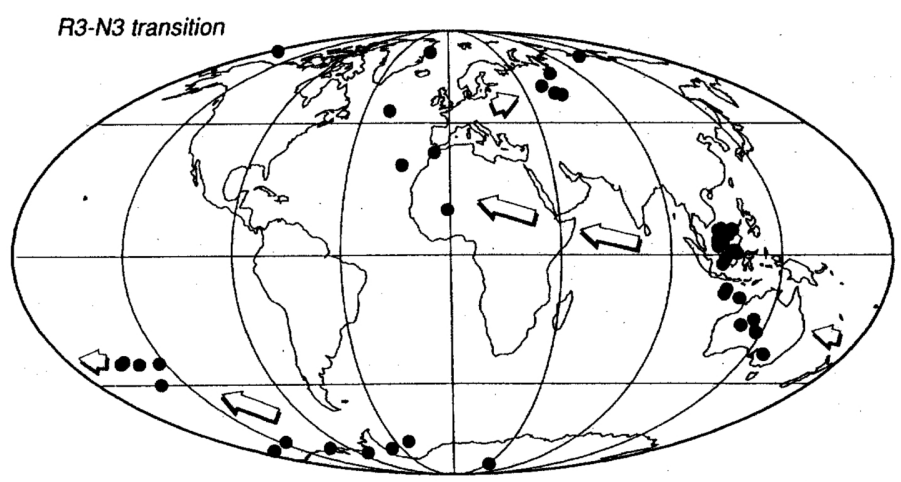

Fig. 4. Virtual geomagnetic poles from most of the lavas in Table 1 of this paper, and six lavas of Table 1 in KRISTJANSSON $e t$ al. (1980). 
Table 1. Palaeomagnetic results from R3-N3 boundary lavas.

\begin{tabular}{|c|c|c|c|c|c|c|c|c|}
\hline 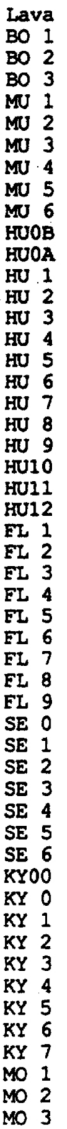 & $\begin{array}{l}N \\
4 \\
4 \\
4 \\
5 \\
4 \\
4 \\
4 \\
4 \\
5 \\
4 \\
5 \\
5 \\
5 \\
5 \\
4 \\
4 \\
6 \\
6 \\
5 \\
4 \\
4 \\
4 \\
4 \\
5 \\
4 \\
5 \\
4 \\
4 \\
4 \\
4 \\
4 \\
3 \\
5 \\
4 \\
4 \\
6 \\
4 \\
6 \\
6 \\
5 \\
5 \\
5 \\
4 \\
4 \\
4 \\
6 \\
4 \\
4 \\
4 \\
4 \\
4\end{array}$ & $\begin{array}{r}\text { Dec } \\
47 \\
51 \\
103 \\
220 \\
194 \\
203 \\
46 \\
131 \\
137 \\
164 \\
215 \\
39 \\
45 \\
50 \\
49 \\
49 \\
52 \\
52 \\
48 \\
48 \\
48 \\
49 \\
61 \\
293 \\
53 \\
49 \\
43 \\
47 \\
45 \\
46 \\
180 \\
47 \\
292 \\
37 \\
52 \\
50 \\
26 \\
5 C A T 7 \\
157 \\
284 \\
36 \\
45 \\
47 \\
46 \\
44 \\
155 \\
205 \\
5 \\
59 \\
61 \\
103\end{array}$ & $\begin{array}{r}\text { Inc } \\
-32 \\
-23 \\
-87 \\
-82 \\
-66 \\
-70 \\
-20 \\
-87 \\
-85 \\
-74 \\
-72 \\
-62 \\
-34 \\
-20 \\
-18 \\
-24 \\
-36 \\
-26 \\
-20 \\
-18 \\
-19 \\
-18 \\
+71 \\
-69 \\
-49 \\
-26 \\
-21 \\
-22 \\
-21 \\
-22 \\
+71 \\
+70 \\
-68 \\
-66 \\
-48 \\
-34 \\
-73 \\
T E R \\
+73 \\
-66 \\
-66 \\
-63 \\
-53 \\
-32 \\
-20 \\
+58 \\
+82 \\
+85 \\
+67 \\
+68 \\
-78\end{array}$ & $\begin{array}{r}\text { Lon } \\
114 \\
109 \\
142 \\
198 \\
307 \\
279 \\
113 \\
148 \\
137 \\
47 \\
254 \\
129 \\
117 \\
109 \\
110 \\
111 \\
111 \\
109 \\
112 \\
111 \\
111 \\
110 \\
57 \\
204 \\
113 \\
111 \\
116 \\
113 \\
114 \\
113 \\
339 \\
70 \\
206 \\
132 \\
114 \\
112 \\
143 \\
N 5 A R \\
353 \\
212 \\
133 \\
124 \\
120 \\
116 \\
115 \\
359 \\
328 \\
342 \\
66 \\
62 \\
109\end{array}$ & $\begin{array}{l}\text { Lat } \\
+01 \\
+05 \\
+65 \\
-73 \\
-72 \\
-75 \\
+08 \\
+67 \\
-71 \\
-81 \\
-72 \\
-22 \\
+01 \\
+06 \\
+08 \\
+05 \\
-03 \\
+03 \\
+07 \\
+08 \\
+08 \\
+08 \\
+59 \\
-37 \\
-13 \\
+03 \\
+08 \\
+06 \\
+07 \\
+07 \\
+30 \\
+65 \\
-36 \\
-26 \\
-12 \\
-01 \\
-34 \\
\text { INTRUS } \\
+34 \\
-37 \\
-27 \\
-24 \\
-15 \\
+01 \\
+08 \\
+15 \\
+49 \\
+75 \\
+56 \\
+56 \\
-60\end{array}$ & 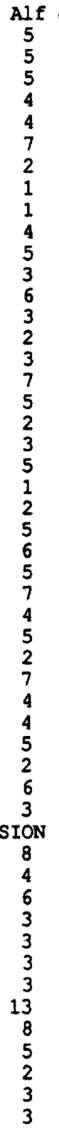 & $\begin{array}{r}\text { J100 } \\
0.7 \\
0.8 \\
1.4 \\
6.0 \\
6.0 \\
0.3 \\
1.6 \\
1.0 \\
3.7 \\
9.9 \\
16.8 \\
0.5 \\
1.1 \\
1.1 \\
2.1 \\
1.5 \\
1.4 \\
1.4 \\
1.5 \\
1.8 \\
1.6 \\
1.7 \\
5.5 \\
2.2 \\
1.6 \\
1.1 \\
1.8 \\
1.6 \\
1.6 \\
0.8 \\
0.9 \\
3.0 \\
2.1 \\
1.2 \\
1.3 \\
1.4 \\
1.7 \\
0.9 \\
0.9 \\
3.5 \\
1.5 \\
1.7 \\
1.6 \\
1.2 \\
1.4 \\
0.6 \\
0.8 \\
1.7 \\
4.4 \\
2.7 \\
1.5\end{array}$ & $\begin{array}{c}\text { Pol } \\
\text { E } \\
\text { E } \\
\mathbf{R} \\
\mathrm{R} \\
\mathrm{R} \\
\mathrm{R} \\
\mathrm{E} \\
\mathrm{R} \\
\mathrm{R} \\
\mathrm{R} \\
\mathrm{R} \\
\mathrm{RT} \\
\mathrm{E} \\
\mathrm{E} \\
\mathrm{E} \\
\mathrm{E} \\
\mathrm{E} \\
\mathrm{E} \\
\mathrm{E} \\
\mathrm{E} \\
\mathrm{E} \\
\mathrm{E} \\
\mathrm{N} \\
\mathrm{RT} \\
\mathrm{RT} \\
\mathrm{E} \\
\mathrm{E} \\
\mathrm{E} \\
\mathrm{E} \\
\mathrm{E} \\
\mathrm{NT} \\
\mathrm{N} \\
\mathrm{RT} \\
\mathrm{RT} \\
\mathrm{RT} \\
\mathrm{E} \\
\mathrm{RT} \\
\mathbf{P} \\
\mathrm{NT} \\
\mathrm{RT} \\
\mathrm{RT} \\
\mathrm{RT} \\
\mathrm{RT} \\
\mathrm{E} \\
\mathrm{E} \\
\mathrm{NT} \\
\mathrm{N} \\
\mathrm{N} \\
\mathrm{N} \\
\mathrm{N} \\
\mathrm{R}\end{array}$ \\
\hline
\end{tabular}

$\mathrm{N}$ : number of samples used in averaging. Dec, Inc: declination and inclination of best mean direction for each lava. Lon, Lat: coordinates of virtual geomagnetic pole. Alf: $95 \%$ confidence angle $\left(\alpha_{95}\right)$ for the mean direction, degrees. J100: arithmetic mean remanence intensity after $10 \mathrm{mT}$ AF treatment, $\mathrm{A} / \mathrm{m}$. Pol: polarity. T indicates pole latitude less than $40^{\circ}, \mathrm{E}$ less than $10^{\circ}$.

correlating between the profiles.

Individual lava directions can in many cases be compared to those recorded in T. Sigurgeirsson's 1955-56 notebooks and Figs. 3 and 4 of his 1957 paper. His results are found to be remarkably accurate in almost all cases, in some lavas even within a few degrees of our averages. In Fig. 4, VGP's are plotted from all the flows of Table 1 except BO3, MO3, MU5, 6 (which belong to the R2 zone) and SE4 (possibly disturbed by intrusions or faulting). Figure 4 also includes poles from the flows EP43-45 and SB22-24 of KRISTJANSSON et al. (1980).

Four groups of poles, in definite time sequence, are recorded in the R3-N3 transition: first, a group of poles in the south Pacific, a band crossing the Equator from W-Australia, then there is further westwards movement to a group around NW-Africa, and finally some poles in the Urals. Thus, a wide range of longitudes is covered during the transition; in particular, a tendency for the transitional pole path to pass through the Americas which has been noted in some recent work from elsewhere (LAJ et al., 1991) is not evident. 
As reported already by SIGURGEIRSSON (1957), the transitional lavas which we have sampled are mostly of rather weak remanence intensity, typically 1-2 A/m after $10 \mathrm{mT}$ AF treatment (Table 1), compared to a mean of 3.5-4 A/m for the Esja area lavas in general. They generally do not seem to be suitable for palaeointensity determinations, as they are relatively soft with respect to AF demagnetization. Thus, the remanence intensity in many of the samples drops by more than $40 \%$ on $10 \mathrm{mT}$ treatment, and/or large directional changes occur. The most stable cores in our current collection may be those from the units SE0, FL1-3, MU4 and HU3-11.

\section{Related Work on Transitions/Excursions in SW-Iceland}

\subsection{Absence of geomagnetic events from $R 3$}

The polarity group N3 seems quite variable both in terms of vertical thickness and number of lavas, from a single flow in Botnsdalur valley (BO) to almost $100 \mathrm{~m}$ in $\mathrm{mt}$. Esja (SB). The overall thickness of R3 may be of the order of $500 \mathrm{~m}$ (KRISTJANSSON et al., 1980). In mt. Thyrill, $4 \mathrm{~km}$ due west of our profile BO, BRAGASON (1981) carried out detailed palaeomagnetic measurements on 31 samples from eight units. His profile begins at a block-lava outcrop at $160 \mathrm{~m}$, ending in the main Thyrill olivine tholeiite flowunit series at $250 \mathrm{~m}$. All were reversely magnetized after AF treatment; previous reports by geologists of a normal event (older than N3) in this profile turned out to be due to interference from viscous remanence (VRM) in samples measured in the field. Similarly, a normal "event" inferred from field measurements in the R3 lava pile below Sigurgeirsson's site G (Unit 13 of FRIDLEIFSSON (1973)) was shown to be spurious by KRISTJANSSON et al. (1980).

\subsection{Tentative correlation of $N 3$ with the Húsafell volcano, W-Iceland}

After cessation of activity in the Húsafell central volcano and a period of erosion, a hyaloclastite and normally magnetized lavas were deposited unconformably on top of the succession. In the paper of MCDOUGALL et al. (1977) this group is represented by the "8th glacial horizon" and lava flows NT107 through 113, which yielded rather poor magnetic results and were not sampled adequately. Resampling of these flows by BRAGASON (1981) has shown that most yield low-latitude reverse virtual poles, somewhat similar to those at the R3-N3 boundary in Esja. This correlation is however not supported by the available K-Ar dates of 1.63 M.y. for flow NT107, 1.9 M.y. for a rhyolite in Esja younger than N3, but uncertainties in either date due to alteration and other factors may possibly reach $0.1-0.2$ M.y.

\subsection{The N4-R3 boundary (Gauss-Matuyama)}

The N4-R3 transition, which most likely corresponds to the Gauss-Matuyama boundary, was first sampled by SIGURGEIRSSON (1957) at a site in W-Iceland (approx. $64^{\circ} 28^{\prime} \mathrm{N}, 21^{\circ} 15^{\prime} \mathrm{W}$ ) yielding poles in the Japan-Australia region (Fig. 5). That site has not been mapped or resampled.

Presumably the same boundary was sampled by WILSON et al. (1972) in two profiles in the Esja area. A third boundary section was sampled by KRISTJANSSON et al. (1980, see their Fig. 1 for locations) in lavas EN6-16 and in the overlapping profile SA, also in the Esja area. Furthermore, some lavas originally sampled by MCDOUGALL et al. (1977) around NT95 and later resampled (BRAGASON, 1981) may belong to the same transition.

Although the magnetic stability of the samples from the last two groups of lavas was not ideal, they indicate that there was much irregular movement of the virtual pole at or close to the Gauss-Matuyama boundary (Fig. 5). Hence, direction results from this boundary seem to be less promising for use in detailed stratigraphic correlations than those of the R3-N3 boundary (Fig. 4).

\subsection{Palaeointensities}

SHAW $(1975,1989)$ reported that the palaeointensity values obtained with his method on many samples from the R3-N3 boundary, largely the equatorial group of our Fig. 4, were low. However, four samples indicated that an increase in palaeointensity by a factor of 3 or more occurred during the transition, 


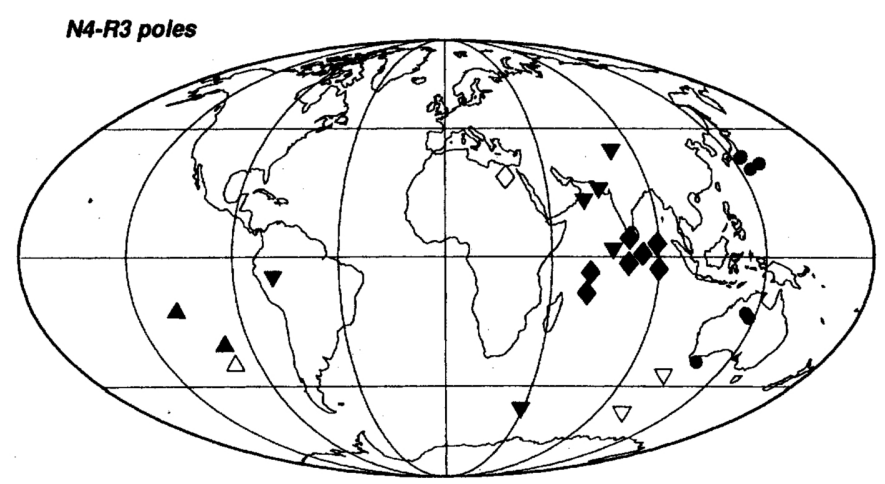

Fig. 5. Intermediate virtual poles at or near the N4-R3 (Gauss-Matuyama) boundary in SW-Iceland. Circles: data from SiguRGEIRSSON's (1957) Fig. 3, one sample per flow. Diamonds: Data from WiLson et al.'s (1972) profiles K and J, two samples per flow except one with a single sample (open diamond). Triangles pointing up: Unpublished results from profile NT of MCDougall et al. (1977). Triangles pointing down: Data from profiles EN and SA of KRISTJANSSON et al. (1980). The triangles represent three samples per flow; in the open triangles, $\alpha_{95}$ values were high $\left(\sim 15^{\circ}\right)$.

without a significant accompanying change in field direction. This result would imply that amplitudes of all major currents in the core can change in unison by the above amount. On the other hand it must be pointed out that the experimental methods used on these particular samples have been demonstrated to yield spuriously high results from similar material on a number of other occasions (KRISTJANSSON, 1985; ROBERTS and SHAW, 1990; ROLPH, 1991).

We suggest that the palaeointensity values from the above four R3-N3 samples need substantiating by additional work before they can be accepted as convincing evidence for strong equatorial dipoles. Such behaviour would in any case be a rare phenomenon, as demonstrated by KRISTJANSSON and MCDOUGALL's (1982) statistical study on remanence intensities in Icelandic lavas. These authors (p. 283) also showed that interpretion of remanence intensity vs. VGP latitude data in terms of Gaussian statistics, as has sometimes been done to support the suggestion of strong equatorial fields, is not appropriate.

\section{The R5-N5 Transition}

WILSON et al. (1972) show a map of pole positions from several lavas having "anomalous" remanence directions in their profile $\mathrm{C}$, in the Villingadalur corrie of mt. Skardsheidi at $64^{\circ} 30^{\prime} \mathrm{N}, 21^{\circ} 34^{\prime}$ $\mathrm{W}$, just north of our Fig. 2. According to mapping by Tr. Einarsson, these directions represent the R5-N5 boundary which may be the transition between the Gilbert and Gauss chrons. We have resampled the transition in a profile named SH(Fig. 6) a few hundred m southwest of that of Wilson et al., in good exposures. The lavas are of average thickness compared to the lava pile in W- and SW-Iceland in general, thin compound flows like those of Fig. 3 being absent. The common presence of interbasaltic sediments in profile $\mathrm{SH}$ also indicates that the time represented by a flow is not much less than the mean for W-Iceland, which is of the order of ten thousand years (KRISTJANSSON and MCDOUGALL, 1982, Table 1b).

Magnetic data from individual lavas following AF demagnetization to $20-30 \mathrm{mT}$ as required, are listed in Table 2, and the inferred virtual pole positions are shown in Fig. 7. The lavas are generally stable in direction after removal of viscous remanence by $10 \mathrm{mT}$ treatment, with excellent within-flow agreement. However, the primary remanence is rather soft and does not seem to be promising for palaeointensity measurements. The transition is seen to include at least 9 flows of pole latitudes below $45^{\circ}$, in various longitudes between $60^{\circ}$ and $220^{\circ} \mathrm{E}$.

This transition hence seems to be quite irregular in nature. Our profile can easily be correlated with that of WILSON et al. (1972) using their palaeomagnetic directions (R. L. Wilson, personal communication 


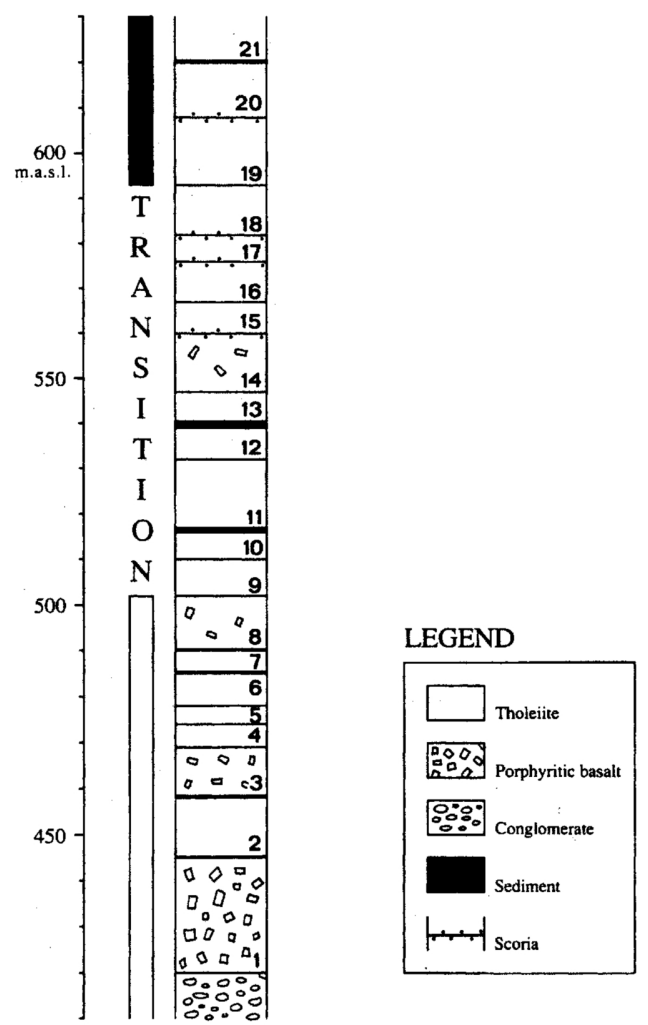

Fig. 6. Geological section of profile SH across the R5-N5 boundary in mt. Skardsheidi, SW-Iceland. Interbasaltic sediments reach $1.5 \mathrm{~m}$ in thickness.

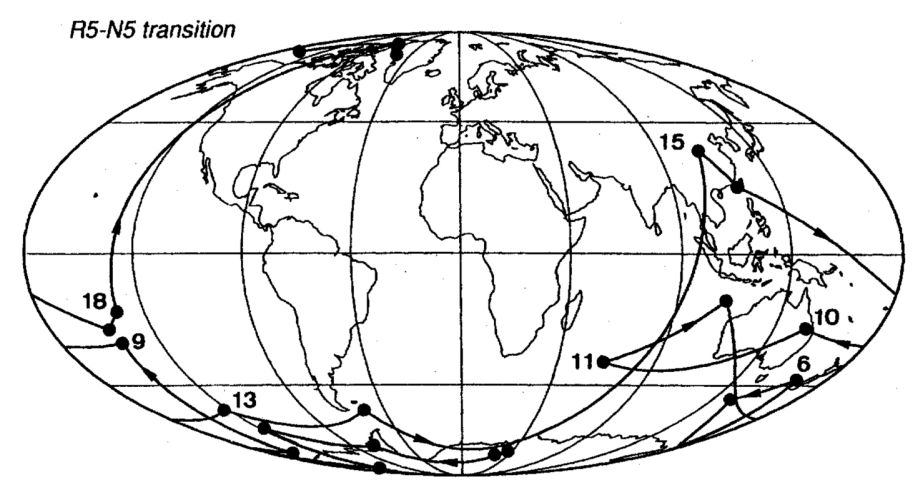

Fig. 7. Virtual-pole path as recorded at the R5-N5 boundary in mt. Skardsheidi (Fig. 6).

1972) and lava petrology. One additional detail of the pole path occurs in their data, probably because of lateral wedging out of flows. The only other site in Iceland where this transition may have been sampled for laboratory measurements, is in mt. Akrafjall (KRISTJANSSON et al., 1980). There it seems however represented at most by one unstable flow, FA28. 
Table 2. Palaeomagnetic results from R5-N5 boundary lavas (Fig. 6).

\begin{tabular}{|c|c|c|c|c|c|c|c|c|}
\hline Lava & $\mathrm{N}$ & $\mathrm{Dec}$ & Inc & Lon & Lat & Alf & $\pi 100$ & Pol \\
\hline SH I & 4 & 160 & -70 & 31 & -75 & 4 & 8.2 & $\mathrm{R}$ \\
\hline SH 2 & 4 & 154 & -70 & 41 & -73 & 3 & 5.5 & $R$ \\
\hline SH 3 & 4 & 204 & -67 & 287 & -71 & 7 & 4.6 & R \\
\hline SH 4 & 4 & 241 & -74 & 228 & -63 & 4 & 8.1 & $\mathrm{R}$ \\
\hline SH 5 & 4 & 195 & -78 & 226 & -83 & 7 & 5.5 & $R$ \\
\hline SH 6 & 4 & 346 & -79 & 165 & -43 & 3 & 3.0 & R \\
\hline SH 7 & 4 & 34 & -82 & 145 & -50 & 5 & 1.7 & $R$ \\
\hline SH 8 & 9 & 218 & -81 & 201 & -74 & 3 & 4.7 & $\mathrm{R}$ \\
\hline SH 9 & 5 & 294 & -63 & 208 & -30 & 5 & 1.3 & $\mathrm{RT}$ \\
\hline SH1O & 6 & 14 & -67 & 149 & -25 & 6 & 0.8 & RT \\
\hline SH11 & 6 & 110 & -51 & 66 & -37 & 5 & 1.3 & $\mathrm{RT}$ \\
\hline $\operatorname{SH} 12$ & 6 & 57 & -50 & 110 & -15 & 5 & 2.4 & $\mathrm{RT}$ \\
\hline $\operatorname{SH} 13$ & 4 & 257 & -73 & 222 & -55 & 4 & 2.1 & $\mathrm{R}$ \\
\hline SH14 & 5 & 203 & -52 & 303 & -55 & 4 & 5.2 & R \\
\hline SH15 & 6 & 40 & +30 & 109 & +34 & 5 & 1.4 & NTr \\
\hline SH16 & 6 & 37 & +04 & 118 & +22 & 8 & 1.0 & $\mathrm{NT}$ \\
\hline SH17 & 5 & 299 & -59 & 206 & -25 & 5 & 0.8 & $\mathrm{RT}$ \\
\hline SH1 8 & 5 & 294 & -52 & 213 & -19 & 7 & 1.0 & $\mathrm{RT}$ \\
\hline SH19 & 5 & 338 & +79 & 283 & +80 & 4 & 1.5 & $\mathrm{~N}$ \\
\hline $\mathrm{SH} 2 \mathrm{O}$ & 5 & 322 & +82 & 302 & +74 & 2 & 1.8 & $\mathrm{~N}$ \\
\hline SH21 & 5 & 344 & +69 & 200 & +76 & 6 & 1.8 & $\mathrm{~N}$ \\
\hline
\end{tabular}

Legend as in Table 1.

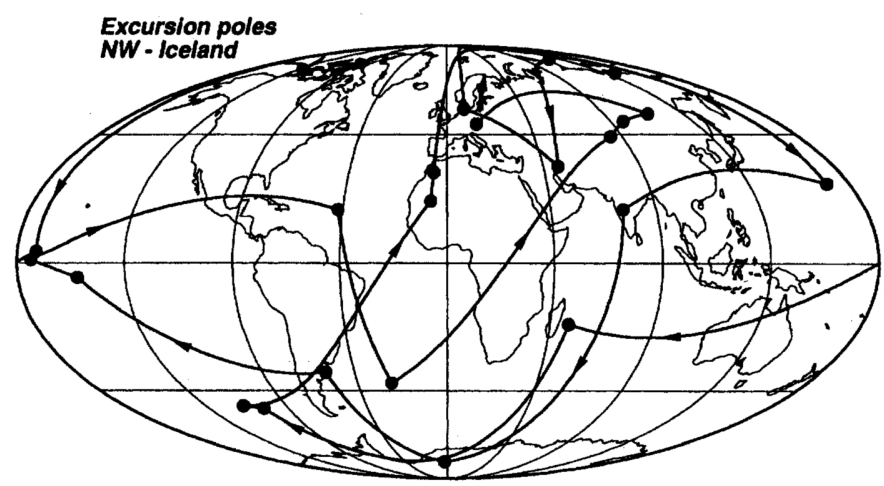

Fig. 8. Virtual-pole path for a complex excursion or subchron of 12.5 to 12.9 M.y. age reported by KRISTJANSSON and JOHANNESSON (1989) from NW-Iceland.

\section{Longitude Distribution of Other Low-Latitude Virtual Poles in Iceland}

Large variations in VGP longitude as seen in the above Figs. 4 and 5, are also noted in some other transitions and excursions in the basalt lava pile of Iceland. The best example of this may be an excursion in NW-Iceland $\left(65^{\circ} 49^{\prime} \mathrm{N}, 22^{\circ} 40^{\prime} \mathrm{W}\right)$ for which palaeomagnetic data were listed in Table III of KRISTJANSSON and JOHANNESSON (1989). The pole path as recorded in their profiles DD, DE and DF is shown in Fig. 8. This excursion which occurred just under $13 \mathrm{M}$.y. ago during a normal polarity chron, is seen to include at least a dozen low-latitude poles and possibly two short periods of reverse polarity.

A more common behaviour is for transitions and excursions to be represented by only a single flow, or by 2-6 flows yielding clustered low-latitude poles. Examples of the last type from SW-Iceland are flows FA45-48 and EY46-50 of KRISTJANSSON et al. (1980). In NP219-230 of MCDOUGALL et al. (1977), later resampled by us (unpublished data) a mid-latitude VGP cluster of at least 12 thin flows occurs during a transition. Figure 12 of KRISTJANSSON and MCDOUGALL (1982) shows the longitudinal distribution of 
470 low- to mid-latitude poles from Icelandic lavas. It seems evident from their results that there is no longterm preference for these poles to occur in any particular longitude bands during the period 2-15 M.y. ago.

\section{The General Reliability of Lava Remanence Directions: Evidence from a Single Extensive Lava Flow}

It is well known (KRISTJANSSON et al., 1980, p. 40) that various effects other than changes in the corederived field may together make a minor $\left(\sim 5^{\circ}\right)$ random and/or systematic contribution to the observed between-unit scatter of remanence directions, even in magnetically stable lavas. In the last few years, several papers have appeared (e.g., CASTRO and BROWN, 1987) which may give the impression that the magnitude of such effects is in some cases sufficient to make lavas and other strongly magnetized materials intrinsically unreliable palaeomagnetic recorders. This would then be a serious problem in the interpretation of results like those reported above, especially in the long-distance correlations at the R3N3 boundary.

By measuring palaeomagnetic directions at widely dispersed sites in a single lava flow, one can make a test of the combined magnitude of several disturbing effects. These include local and regional magnetic anomalies, block rotation during cooling, orientation errors, and to some extent the effects of magnetic field refraction (SOFFEL and SCHURR, 1990) if the magnetization of the flow is variable.

In Iceland, there are opportunities for such a test, notably in the Thjorsa lava (HJARTARSON, 1988). This is one of several lava flows erupted in the highlands of S-Iceland approximately 8600 years B.P. It is at least $140 \mathrm{~km}$ in length to the south coast and has surface outcrops over half of this distance (Fig. 9). This flow is easily recognizable in the field or in drill cores, having an unusual felsparphyric texture.

We have collected samples at six outcrop sites (see Appendix), using our standard methods. Compared to the common type of exposure in Neogene lavas in Iceland, these sites are somewhat

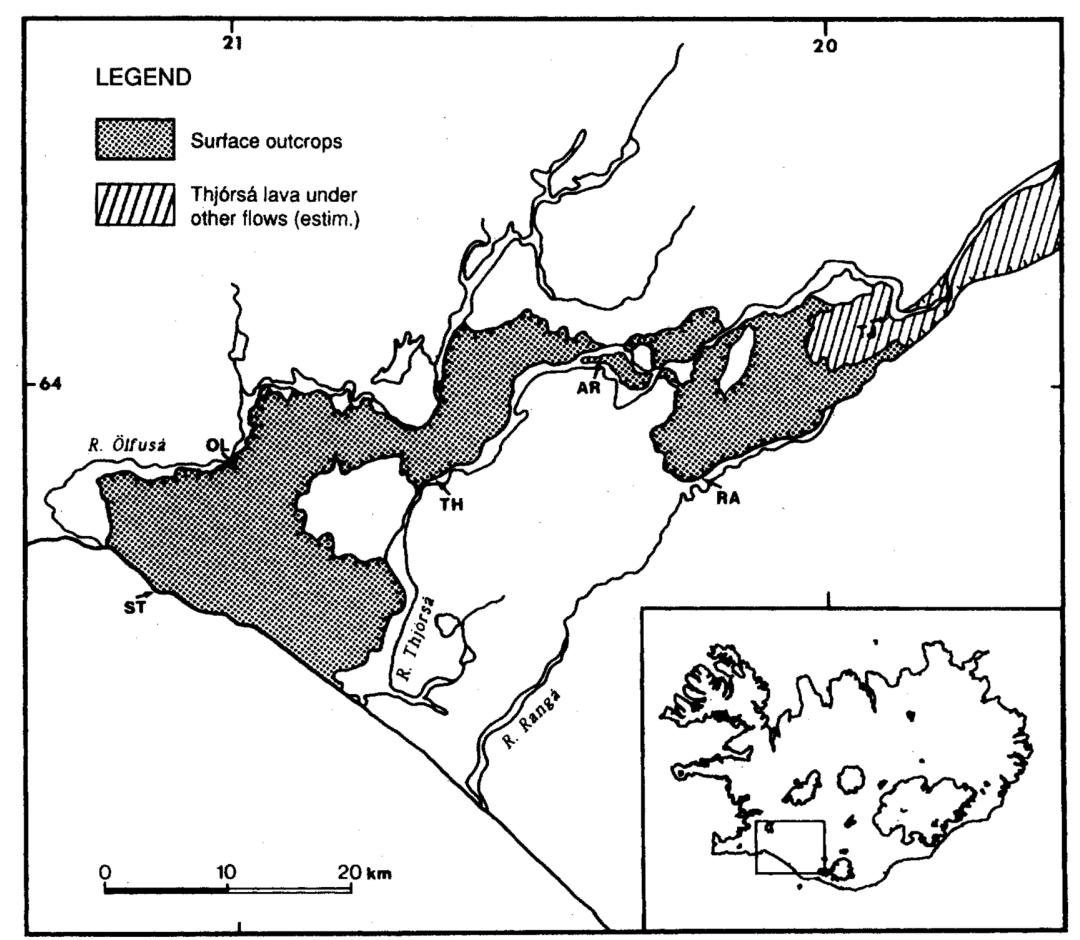

Fig. 9. Sampling sites in the Holocene Thjorsa lava. The map is simplified from HJARTARSON (1988). 
Table 3. Palaeomagnetic results from six sites in the Thjorsa lava (Fig. 9).

\begin{tabular}{lrrlcccc}
\hline Site & N & Dec & Inc & k & Alf & J0 & J00 \\
TH & 11 & 355 & 74.8 & 185 & 3.4 & 21 & 13 \\
ST & 10 & 2 & 76.3 & 229 & 3.2 & 23 & 16 \\
AR & 7 & 11 & 76.3 & 480 & 2.8 & 29 & 16 \\
OL & 10 & 6 & 76.5 & 539 & 2.1 & 13 & 8 \\
RA & 8 & 359 & 79.2 & 2139 & 1.2 & 18 & 14 \\
TJ & 10 & 5 & 79.2 & 574 & 2.0 & 12 & 7 \\
ALL & 6 & 2 & 77.1 & 1410 & 1.8 & 19 & 12 \\
\hline
\end{tabular}
Table 1 .

$k$ : precision parameter for the mean remanence vector. J0: natural remanence intensity, in $\mathrm{A} / \mathrm{m}$. Legend otherwise as in

unfavorable in that they are close to the upper surface of the 20-m thick flow and thus may have moved a little subsequent to solidification. The mean NRM intensity is about $19 \mathrm{~A} / \mathrm{m}$, and the susceptibility of samples is generally in the range $(1-2) \cdot 10^{-3}$ cgs volume units.

Palaeomagnetic results from our sites in the Thjorsa lava are listed in Table 3, showing that the deviation of any site mean from their overall mean direction is less than $3^{\circ}$ of arc. The within-site directional scatter (circular standard deviation) is of the order of $5^{\circ}$, similar to that reported for seven other Holocene lava flows in Iceland by DOELL (1972). Both our cores and those of Doell were sampled over a distance of the order of $50 \mathrm{~m}$ at each site.

These results strengthen our previous belief, based on experience from thousands of lava flows, that the internal consistency of palaeomagnetic directions measured in magnetically stable lavas in Iceland is quite satisfactory. Reasonable care in site selection and experimental procedures must however be exercised, because quality of outcrops as well as the stability of magnetization can sometimes be less than ideal. The fact that series of multiple rapidly erupted (compound) flows in Iceland, such as our HU2-11 of Table 1, commonly give very consistent primary remanence directions, also indicates that local effects are unlikely to generate large spurious scatter in inferred VGP's.

\section{Conclusions and Discussion}

SIGURGEIRSSON (1957) showed that the R3-N3 transition in SW-Iceland consisted mostly of three groups of virtual poles, the groups having quite different longitudes. In the middle group the south-north progress of the pole across the Equator could be followed to some extent.

We have attempted to improve Sigurgeirsson's results on the R3-N3 pole path, firstly by measuring 3-6 samples per lava flow at his profiles A to $\mathrm{G}$ and extending the demagnetization treatment, secondly by locating additional outcrops of the transition. We hope that our efforts at establishing stratigraphic correlations between these (Fig. 3) will be of use to other researchers visiting the outcrops for sampling or mapping purposes.

The present work confirms that Thorbjörn Sigurgeirsson's experimental procedures in his pioneering mid-1950's palaeomagnetic research were of very high quality. He has also selected samples that gave consistently reliable remanence directions, even if only demagnetized to $11 \mathrm{mT}$ peak field. The good agreement between palaeomagnetic direction groups from the R3-N3 transition lavas in the widely separated profiles of Figs. 2 and 3 indicates that local disturbing effects or sampling errors are of minor importance. This conclusion is supported by new work on a single lava where the lateral distance between sampling sites reaches more than twice that of the R3-N3 transition.

The only new detail which we have added to the R3-N3 pole path shown in Figs. 3 and 4 of Sigurgeirsson's 1957 paper, is a fourth group of poles, situated in the Urals area. Of course, any number 
of complications in the actual pole path may have occurred between the four preserved segments. In profiles BO and MU, we did not find any lavas of the N3 zone: if the transition had only been studied in those two profiles, it would have been proper to call it merely an "excursion". It is thus likely that many such excursions of the pole to low latitudes, seen in other lava sequences in Iceland, in fact belong to short reversals.

The agreement of pole-path details between the various R3-N3 transition sites appears to confirm simultaneity in volcanism, possibly on a time scale of centuries or less. This transition is thus an unusually valuable local stratigraphic reference across a distance of more than $20 \mathrm{~km}$. Consequently, the glacial horizon which underlies the transition in mt. Esja (profiles SB, EP of Fig. 2) may for instance be correlated with the sediments and hyaloclastites in the other profiles all the way to Selfjall (profile BO), even if its thickness and other characteristics change considerably at the intervening localities.

We confirm the observation by WILSON et al. (1972) that a complex pole path is recorded during the R5-N5 transition. The N4-R3 path, for which we have less reliable data, also seems to yield transitional poles with widely varying longitudes. So do several others in Iceland, and there is at present no reason to believe that a preference for particular VGP longitude bands is present, at least not when averaged over the period 0-15 M.y. ago.

Our results are somewhat difficult to reconcile with the recent claim by LAJ et al. (1991) of a "remarkable preponderance" of transitional poles to pass through the Americas. We can only point out that directions in Icelandic lavas show a much higher long term between-unit scatter than that estimated by currently popular models of the geomagnetic field (see KRISTJANSSON and MCDOUGALL, 1982; KRISTJANSSON and JOHANNESSON, 1989). Possibly, the arrangement of the field sources in the Earth's core, especially during transitions and major excursions, is such that the field in high latitudes contains a larger random component than that in low latitudes. Also, the low-pass filtering of the directional signal which is caused by the long time constant of remanence acquisition in sediments, may show up certain systematic features of the field direction to a greater extent than do spot readings of the field by lava flows: Judging from the number of lava flows erupted during the apparent periods of instability of the field discussed in the present paper, it seems that some such periods may last as long as 50-100 thousand years.

Conclusions regarding correlation of any of the above-mentioned transitions with similar features observed in other countries or oceans, as well as speculations regarding dipole/nondipole content in the field during these transitions, have to wait until additional reliable K-Ar dates from the Icelandic lava pile are available. Reliable palaeointensity results from the transitional lavas are also required.

We thank Charlotte Mathiesen, Vigdis Hardardottir, Geirfinnur Jonsson, Haraldur Audunsson and Sigurdur Jonsson for assistance with field work and measurements.

Appendix: Description of locations for Figs. 2, 3, 5, and 9

BO: Kidagil gully, mt. Selfjall, Botnsdalur valley. Profile A of SIGURGEIRSSON (1957) is probably some hundreds of $m$ to the west.

MU: Mt. Mulafjall, just east of the farm Ingunnarstadir.

HU: Western side of Husagil gully, behind the farm Thrandarstadir, Brynjudalur valley. Same as Sigurgeirsson's B, see also BRYNJOLFSSON (1956).

FL: Western side of Flugugil gully, mt. Thrandarstadafjall. Same as Sigurgeirsson's C and WILSON et al.'s (1972) A profile.

SE: Western side of Sela river, NW of Haekingsdalur farm.

KY: Eastern side of Kyrgil gully, near Haekingsdalur. Same as Sigurgeirsson's D.

MO: Mödruvallahals ridge, above Mödruvellir farm. EP in mt. Thomyjartindur and SB in mt. Kistufell are close to Sigurgeirsson's F and G profiles respectively. See Fig. 2 of KRISTJANSSON et al. (1980) for geological details. 
SH: R5-N5 boundary site on east side of Villingadalur corrie, mt. Skardsheidi, about half way between the road and waterfalls.

Thjorsa lava sites-TH: Below main road bridge over Thjorsa river, west bank. ST: Beach east of Stokkseyri village. AR: Ames island in r. Thjorsa. OL: east bank of Ölfusa river at Selfoss village. RA: West bank of $r$. Ranga, upstream from Husagardur farm. TJ: Thjofafoss waterfall in $r$. Thjorsa.

\section{REFERENCES}

Bragason, H. O., Paleomagnetic measurements in Jökuldalur valley, unpublished B.S. Hons. Thesis, 47 pp., University of Iceland, 1981 (in Icelandic).

BRYNJOLFSSON, A., Ergebnisse bei partieller Entmagnetisierung des natürlichen Magnetismus isländischer Basalt, Naturwissensch., 43, 154-155, 1956.

Castro, J. and L. Brown, Shallow paleomagnetic directions from historic lava flows, Hawaii, Geophys. Res. Lett., 14, 12031206, 1987.

Doell, R. R., Palaeomagnetic studies of Icelandic lava flows, Geophys. J. R. Astron. Soc., 26, 459-479, 1972.

Einarsson, T., Magneto-geological mapping in Iceland with the use of a compass, Adv. Phys. (Phil. Mag. Suppl.), 6, 232-239, 1957.

Fridleifsson, I. B., Petrology and structure of the Esja Quaternary volcanic region, southwest Iceland, D. Phil. Thesis, 208 pp., Oxford University, 1973.

FridleifSSON, I. B., The geological history of mt. Esja and its surroundings, Arbok Ferdafelags Islands, 141-172, 1985 (in Icelandic).

GeIRsDottir, A., Diamictites of late Pliocene age in western Iceland, Jökull, 40, 3-25, 1991.

HJARTARSON, A., The Thjorsa lava, the largest Holocene lava flow on Earth, Natturufraedingurinn, 58, 1-16, 1988 (in Icelandic, with English summary).

KJARTANSDOTTIR, M. I., The geology of mt. Thrandarstadafjall and Sudurfjall, part III, unpublished B.S. Thesis, 23 pp., University of Iceland, 1976 (in Icelandic).

KRISTJANSSON, L., On "The relationship between the magnitude and direction of the geomagnetic field during the late Tertiary in Eastern Iceland" by N. Roberts and J. Shaw, Geophys. J. R. Astron. Soc., 80, 555-559, 1985.

KRISTJANSSON, L. and H. JOHANNESSON, Variable stability of the Neogene geomagnetic field in Iceland, Phys. Earth Planet. Inter., 56, 124-132, 1989.

Kristjansson, L. and I. MCDougall, Some aspects of the late Tertiary geomagnetic field in Iceland, Geophys. J. R. Astron. Soc., 68, 273-294, 1982.

KRISTJANSSON, L., I. B. FridLEIFSSON, and N. D. WATKINS, Stratigraphy and paleomagnetism of the Esja, Eyrarfjall and Akrafjall mountains, Iceland, J. Geophys., 47, 31-42, 1980.

Laj, C., A. Mazaud, R. Weeks, M. Fuller, and E. Herrero-bervera, Geomagnetic reversal paths, Nature, 351, $447,1991$.

McDougall, I., K. Saemundsson, H. Johannesson, N. D. Watkins, and L. Kristjansson, Extension of the geomagnetic polarity time scale to $6.5 \mathrm{~m} . \mathrm{y}$.: K-Ar dating, geological and paleomagnetic study of a 3,500-m lava succession in western Iceland, Geol. Soc. Amer. Bull., 88, 1-15, 1977.

RoBerTS, N. and J. SHAW, Secondary magnetizations cast doubt on exceptional palaeointensity values from the Lousetown Creek lavas of Nevada, U.S.A., Geophys. J. Int., 101, 251-257, 1990.

RoLPH, T., Anomalous field intensities from Recent and historic lavas (abstract). Internat. Union of Geodesy and Geophysics, XX Assembly, Vienna, IAGA Program and Abstracts, p. 11, Aug. 1991.

SHAw, J., Strong geomagnetic fields during a single Icelandic polarity transition, Geophys. J. R. Astron. Soc., 40, 345-350, 1975.

SHAw, J., Paleomagnetic field: intensity, in The Encyclopedia of Solid Earth Geophysics, edited by D. E. James, pp. 872-876, Van Nostrand Reinhold, New York, 1989.

Sigurgeirsson, T., Direction of magnetization in Icelandic basalts, Adv. Phys. (Phil. Mag. Suppl.), 6, 240-246, 1957.

SOFFEL, H. C. and K. SCHURR, Magnetic refraction studied on two experimental kilns, Geophys. J. Int., 102, 551-562, 1990.

WALKER, G. P. L., Zeolite zones and dyke distribution in relation to the structure of the basalts in eastern Iceland, J. Geol., 68, 515-528, 1960.

Wilson, R. L., N. D. Watkins, T. Einarsson, T. Sigurgeirsson, S. E. Haggerty, P. J. Smith, P. Dagley, and A. G. MCCormack, Palaeomagnetism of ten lava sequences from south-western Iceland, Geophys. J. R. Astron. Soc., 29, 459-471, 1972. 